\title{
The Art of the Deal, The Arts of Democracy: Trump, Dewey, and Democracy ${ }^{1}$
}

Nancy S. Love

"I just want to build. After all, that's what I do best."

--Donald Trump (1997)

"A Trump building is like someone has planted a gold bar, instead of a flag, in unclaimed land."

--Nick Hilton (2018)

"A country is not a hotel, and it's not full."

--Yo-Yo Ma (2019)

"This is a land...uncharted waters, constitutionally." --Lindsay Graham (2019)

\section{The Neoliberal Imaginary: Trump as Artist}

“I don't do it for the money. I've got enough, much more than I'll ever need. I do it to do it. Deals are my art form. Other people paint beautifully on canvas or write beautiful poetry. I like making deals, preferably big deals. That's how I get my kicks" (Trump 2015: 1).

Donald Trump's politics has been variously described as "neoliberal," "nationalist," "authoritarian," "populist," and even "fascist," and all of these descriptors are appropriate in some respects (Beinart 2016; Friedman 2017; McCarthy 2018; McWilliams 2016; Stanley 2019). In this article, I explore the linkages between Trump, neoliberalism, and fascism through what may seem an unlikely aspect of his politics, that is, his artistry as a candidate and now as the president. In elevating deal-making to an art form, Trump is not unique. Fascist leaders have long fancied themselves as artists and regarded politics as artistry. ${ }^{2}$ In addition to political propaganda, ${ }^{3}$ classical fascist leaders deployed the symbolic politics of architecture, film, music, ${ }^{4}$ theater, and sculpture. ${ }^{5}$ According to Susan Sontag, Leni Riefenstahl's films, especially Triumph of the Will, exemplify the major features of National Socialist aesthetics: "the ideal of life as art; the cult of beauty; the fetishism of courage; the dissolution of alienation in ecstatic feelings of community; the repudiation of the intellect; the family of man (under the parenthood of leaders)" (1980: 
95-96). Sontag claims that a deep longing for aspects of fascist aesthetics persists in the guise of romanticism among many liberal democrats. Their aesthetic desires can be seen "in such diverse modes of cultural dissidence and propaganda for new forms of community as the youth/rock culture, primal therapy, anti-psychiatry, Third World camp-following, and belief in the occult" (Sontag 1980: 96). She worries that liberal democrats often fail to "detect the fascist longings in their midst," partly because they tend to relegate aesthetics and politics to separate spheres, private and public, respectively (Sontag 1980: 96).

Sontag's argument is controversial given the institutional differences between liberal democratic and fascist regimes. Yet she makes crucial points about the continuities between the aesthetic politics of fascism and liberal democracy, including how art as propaganda can distract, fascinate, and mesmerize mass publics, and thereby "normalize" the otherwise unimaginable. In Democratic Artworks, Charles Hersch claims that the capacity of the arts to engage and educate democratic citizens by appealing to emotional and sensory, as well as cognitive experiences, is double-edged. The arts not only strengthen the bonds between citizens and democratic values but can also undermine them by engulfing the individual in the collective. Of Riefenstahl's Triumph of the Will, Hersch writes, "Ironically, artworks may undermine democracy precisely because of their ability to create shared experience" (qtd. in Hersch 2018: 248).

Neoliberalism modulates these continuities between liberal and fascist aesthetics in important ways. In his defense of market freedoms, Milton Friedman famously said "the consistent liberal is not an anarchist." Classical liberals, like Friedman, rely on government institutions to establish and enforce "the rules of the game," create communication and transportation infrastructures, address "neighborhood effects," and care for those in need (2002: 34). Neoliberals place a greater emphasis on individual entrepreneurship and market freedoms, often earning them the label "economic libertarians." David Harvey defines neoliberalism as "a theory of political economic practices that proposes that human well-being can best be advanced by liberating individual entrepreneurial freedoms and skills within an institutional framework characterized by strong private property rights, free markets, and free trade" (qtd. in Abu-Hamdi 2017:103). For neoliberals, every individual is a capitalist entrepreneur with equal access to free markets. According to Walter Benn Michaels (2011), when compared to classical liberalism, neoliberal capitalism, with its economic libertarianism, manifests "formlessness" and a "lack of grounding." Unlike classical liberalism's "rules of the game," neoliberalism is a "free-for-all." Nick Srnicek argues that the neoliberal combination of deregulated global markets and unregulated social media, in particular, creates a sense of chaos that many people find overwhelming. The neoliberal world (dis)order involves "a complexity that is too dense, too thick, too intense, too speedy, too fast for our brains to decipher" (Berardi, qtd. in Srnicek 2015). For many, the unfortunate result is "a deficiency in cognitive mapping" (Jameson, qtd. in Srnicek 2015). This deficiency arises even though neo- and classical liberals ultimately agree that individual successes or failures depend on rationality, industry, talent - and a bit of luck.

In his recent article, "Our Increasingly Fascist Public Discourse," Jason Stanley argues that Social Darwinism, repackaged as evolutionary biology or developmental psychology, provides the missing link between liberalism, neoliberalism, and fascism. To forge this link, one need only shift from individual to group struggles for racial and/or national survival and from individual to group successes based on racial and/or national character. Stanley analyzes the rhetoric in myths of racial and national superiority, specifically, linguistic constructions of "us" vs. "them," that shape the resurgent Eurocentrism of the American alt right. His analysis reveals how these 
structural inequalities continue to undergird the superficial chaos of neoliberalism. As we will see, Trump deploys Social Darwinism to link neoliberalism, liberalism, and fascism, and he draws his Social Darwinism from the unlikely source Stanley identifies, economic libertarianism (2019).

The arts have long provided cognitive maps that helped individuals to order a chaotic world or to make sense of their inner and outer experiences. In The Structural Transformation of the Public Sphere (1991), Jürgen Habermas famously argued that the literary public sphere helped create an engaged, informed citizenry capable of reflective judgment and, when necessary, democratic dissent. Yet today, many artists find it increasingly difficult to sustain the distance from capitalist markets necessary to resist rather than mirror neoliberal reality (Srnicek 2015; Elliott and Harkins 2013). Some scholars have argued that the aesthetic dimension that Herbert Marcuse, like Habermas, once regarded as a site of political resistance has all but succumbed to a one-dimensional neoliberal world (Lebow 2019).

Enter Donald Trump, who says, "deals are my art form." How does Trump's "art of the deal" mirror the superficial chaos and structural inequalities of neoliberalism? In the next three sections, I explore how Trump uses the "art of the deal" to create buildings, crowds, and walls. I argue that his "art of the deal" materializes and normalizes the aesthetics of neoliberal capitalism. I emphasize two of Trump's -- albeit ghostwritten -- early books because it is there that he told the American public "what he does" long before they elected him president. Regarding deal-making, Trump clearly identified his common denominator: "What I understand more than anything else is people. Deals are people, they are not deals, and if you don't have a deeper understanding of people and their motives, you can never become a great dealmaker (1997: 133).”

\section{Trump as Artist: Dealing in Buildings}

"It's [Trump Tower atrium] larger than life, and walking through it is a transporting experience, almost as if you're in a wonderland"

(Trump 2015: 175).

Before he assembled the crowds that chant "BUILD THAT WALL" and "SEND HER BACK," Trump was already building things. Expressing his frustration with bureaucratic processes for approving his construction projects, Trump wrote: "I just want to build. After all, that's what I do best" (2015: 345). Build he has - Trump Parc, Grand Hyatt Hotel, Trump Plaza Hotel, Trump Castle Hotel and Casino, Taj Mahal, Trump Marina, Trump Plaza of the Palm Beaches, and restorations of Grand Central Terminal, Wollman Skating Rink, 40 Wall Street, Mar-a-Lago - to mention only a few prominent examples in the contiguous United States. When discussing his buildings, Trump reiterates several key themes. They are big and dominate the skylines of Atlantic City and New York City. "The skyline of Atlantic City says TRUMP - just like the skyline of New York City says TRUMP” (2015: 27). They are beautiful and their splendor transports people into another reality. Of 40 Wall Street, Trump says, he was "mesmerized by its beauty and its splendor" and "Buildings like 40 Wall Street keep me going" and, of Mar-a-Lago, that "The house had a grandeur I didn't know existed - certainly not in the real world" (2015: 46, 62). Trump Tower atrium is "larger than life, and walking through it is a transporting experience, almost as if you're in a wonderland" (1997: 175). Trump also stresses that his buildings are to be enjoyed to bring people pleasure. Again, regarding Mar-a-Lago, he says, "I'm creating a masterpiece, something people can enjoy for years to come" (1997: 80). 
Trump attributes the deal-making ability that helps him create buildings - and now public policies -- to his gut, his instincts, even his DNA, more than his intelligence. He says, "I buy buildings before I know what I'm going to do with them. It's my instinct, my sense, I know it's going to work out" (1997: 66). In his business and political deal-making, he resists established structures, saying 'You can't be imaginative or entrepreneurial if you've got too much structure. I prefer to come to work each day and just see what develops" and "I'll wing it and things will work out" (2015: 1). He also refuses to become too attached to any particular deal: "I like to keep every option open in life" (2015: 293). With this approach, he underscores the chaos of neoliberal capitalism with its fluctuating global markets.

Like neoliberals, he has little patience with political-legal institutions, procedures, and regulations. As Trump relates the story of NYC's cost overruns and repeated delays in reconstructing Wollman Rink, it was "a simple, accessible drama about the contrast between governmental incompetence and the power of effective private enterprise" (2015: 317). Personal leadership was required to move beyond the legal restrictions hampering progress, and such leadership meant getting the job done through "sheer force of will," if necessary (2015: 316). By comparison, democratic processes are too fickle: "I couldn't believe that the government would allow deals to be made and then wipe them out. It's one thing to establish a new set of guidelines. It's another thing to say guess what, the rules you were playing by and basing already done deals on are dead" (1997: 10). Trump compares the dishonesty and disloyalty of public officials to gamblers, and he gives the latter higher marks: "Gamblers are honorable, in their own way - at least about gambling. When a deal is made, they usually abide by it" (1997: 32).

Of course, Trump's buildings ARE structures that shape interactions in public and private spaces in significant and lasting ways. In a neoliberal capitalist economy, which reduces many people to precarity, buildings can represent surrogate agency by influencing the environment of a community and providing speculators with profits, whether or not the project succeeds (Abu-Hamdi 2017). Beyond the needs they serve for their investors, residents, and visitors, the structures of Trump's buildings have characteristic features that symbolize a particular - white, male -- form of agency. They boast phallic designs, skyline renditions of Trump's personal credo: "Be strong, be firm, be fair. But, if someone tries to screw you, screw them back harder than they ever got screwed before" (1997: 228). On many Trump buildings, his name - TRUMP -- is displayed in large, gold, capital letters. The exterior windows of reflector glass on TRUMP Tower provide an endless mirror, a skyline reflecting pool worthy of Narcissus. ${ }^{6}$ Extravagant interior décor associates patrons with the Trump family's glamorous lifestyle. In this neoliberal aesthetic, class, and other structural inequalities seemingly disappear: we are all entrepreneurs who could make deals if we only chose to do so (Michaels 2011).

In his autobiographies, Trump moves effortlessly between stories of beautiful buildings and beautiful women, including his wives and daughter. The lines between private and public, intimacy and community, subject and object are confused -- and confusing -- here. In Trump's neoliberal aesthetic, the public faces and spaces of buildings are dominated by clean, cold surfaces. Reflector glass fills its exterior windows and smooth marble covers their interior walls. Both surfaces make it difficult to tell what - really, who - is on the inside and the outside. Visitors are simultaneously included and excluded from the(ir) grandeur and splendor; Trump's greatness becomes theirs, but only by ambiguous association.

Aesthetic parallels emerge here with Trump's barely veiled sexual innuendos. In The Art of the Comeback, Trump follows his chapter on the Miss Universe pageant deal, "Master of the 
Universe, How I Got the Beauty Pageant," with the chapter on "Trump Tower, Old Faithful," and then two chapters on "The Women In (and Out) of My Life" and "The Art of the Prenup: The Engagement Wring." In another chapter, "The Press and Other Germs," Trump writes about his fear of contamination and describes himself as a "germ freak," who (like Mussolini) hates shaking hands. Katie Johnson, who alleges that Trump raped her when she was a 13-year-old virgin, has related that no one at sex parties was permitted to touch Trump's penis without gloves (Mikkelson 2016). Yet, according to Stormy Daniels and Karen MacDougal, Trump refused protection for intercourse (CNN 2018a \& b). Like Trump Tower, Trump protects his "edifice" from external contaminants; his buildings break the skyline like he penetrates women's bodies.

What ultimately seems most important here is that Trump's buildings are big and tall, a feature that George Will, who would later criticize Trump, once argued made him quintessentially American. Will wrote of Trump's plans to build the world's tallest building in NYC: "Donald Trump is not being reasonable. But, then, man does not live by reason alone, fortunately. Trump, who believes that excess can be a virtue, is as American as Manhattan's skyline, which expresses the Republic's erupting energies. He says the superskyscraper is necessary because it is unnecessary. He believes architectural exuberance is good for us [and] he may have a point. Brashness, zest and élan are part of this country's character" (qtd. in Trump, 2015: 341, emphasis mine)." The Trump crowds wearing "Make America Great" hats and shouting, "BUILD THAT WALL" and, more recently, "Keep America Great" hats and "SEND HER BACK" vicariously experience this "brashness, zest, and élan." They also reflect a specifically American brand of white supremacist, capitalist, and patriarchal neoliberalism.

\section{| Trump as Artist: Dealing in Crowds}

"The crowds at my Rallies are far bigger than they have ever been before, including the 2016 election.
Never an empty seat in these large venues, many thousands of people watching screens outside.
Enthusiasm \& Spirit is through the roof. SOMETHING BIG IS HAPPENING - WATCH!"

(Trump 2018)

In The Crowd: A Study of the Popular Mind, Gustav Le Bon famously defines the "organized" or "psychological" crowd as "an agglomeration of men [that] presents new characteristics very different from those of the individuals composing it. The sentiments and ideas of all the persons in the gathering take one and the same direction, and their conscious personality vanishes. A collective mind is formed..." (2001: 13). For Le Bon, although crowds evoke so-called primitive sentiments, they cannot be reduced to primal hordes or updated tribes. In order to organize psychologically, modern crowds do not require physical proximity; shared influences - ideas, images, and leaders -- suffice. ${ }^{7}$

Electoral crowds, in particular, demonstrate the newfound democratic power of the people. Le Bon defines electoral crowds as "collectivities invested with the power of electing the holders of certain functions" (2001: 100-107; 101). Electoral collectivities are "heterogeneous crowds," because they form without regard to common features among their members. Further, their "action is confined to a single clearly determined matter, namely, to choosing between different candidates" (Le Bon 2001: 101). Although they are more than mere aggregations, electoral crowds do not display all of the qualities Le Bon associates with popular assemblies and protest movements. He writes: "of the characteristics peculiar to crowds, they [electoral crowds] display... 
slight aptitude for reasoning, the absence of the critical spirit, irritability, credulity, and simplicity" (2001: 101).

According to Le Bon, the leader's prestige is crucial to create an electoral crowd. He writes that "personal prestige can only be replaced by that resulting from wealth. Talent and even genius are not elements of success of serious importance" (2001: 101). Le Bon claims that voters rarely choose a candidate from their own ranks, because such individuals lack prestige. Regarding prestige, Trump's promise to voters is to restore and sustain America's greatness, a quality he associates with business acumen and financial success - neoliberal values. Although white voters across economic classes supported Trump, he was particularly attractive to white working-class male voters. According to McAdam's, Trump offers them a compelling story of his - and American greatness: “'Here's the way I work,' he [Trump] writes in Crippled America: How to Make America Great Again,...'I find the people who are the best in the world at what needs to be done, then I hire them to do it, and then I let them do it ... but I always watch over them"' (qtd. in McAdams 2016). Trump presents himself to working-class white males as the boss whose investments provide good jobs and support the American economy. His red baseball cap symbolizes his ties to the white working-class; it portrays a leader who embodies, elevates, and employs them. However, such a political leader is also a product of the economic system and he, too, can easily be replaced (Lebow 2019). The media emphasis on Trump's individual achievements misses how his self-proclaimed business acumen typifies neoliberal values; it mistakes the symptom for cause (Lebow 2019).

Le Bon describes three additional techniques candidates deploy to gather support: affirmation, repetition, and contagion. As he puts it: 1)"Affirmation pure and simple, kept free of all reasoning and all proof, is one of the surest means of making an idea enter the mind of crowds"; 2 ) "the thing affirmed comes by repetition to fix itself in the mind in such a way that it is accepted in the end as a demonstrated truth"; 3)and, "when an affirmation has been sufficiently repeated and there is unanimity in this repetition....what is called a current of opinion is formed and the powerful mechanism of contagion intervenes" (2001: 72-73, emphasis mine). Together these techniques build the electoral constituency that can empower a candidate.

Trump's campaign strategies, especially online, deal in these techniques Le Bon identifies. First, affirmation: Trump's appeals to white working-class voters are a defense of the uninformed voter and a critique of policy experts (Sullivan 2016; Shafer and Wagner 2019). During the primary, Trump had 6.8 million Twitter followers, making him the most popular presidential candidate on Twitter (Lee 2016). He now has 55 million followers, though more than $60 \%$ of them may be fake, according to the software marketing firm SparkToro. This compares to estimates of $41.5 \%$ (Pence), 40.9\% (Obama), and 33.7\% (Warren) fake followers for other politicians (Campoy, 2018). Whatever the actual number, Trump's Tweets bypass and often directly attack quality media and detailed policy analyses (Habermas 2006). They also raise questions about the meaning indeed, the very possibility - of factual knowledge. According to PolitiFact, Trump's mendacity is "extreme" even in an era when politicians are expected to lie. They report that only 5\% of the claims made by Trump are true, $10 \%$ are mostly true, $14 \%$ are half true, $21 \%$ are mostly false, $35 \%$ are false, and 15\% are 'pants on fire.' Combining the last three numbers shows that 71\% of Trump's statements are mostly to flagrantly false (2019). "During the 2016 campaign, the corresponding figures for Ted Cruz, John Kasich, Bernie Sanders, and Hillary Clinton, respectively, were 66, 32, 31, and 29 percent" (McAdams 2016). The Fact Checker reports that through December 30, 2018 and the first 710 days of his presidency, Trump made 7,645 suspect 
claims for an average of 39 false or misleading statements per day (Kessler, Rizzo, and Kelly 2018). Trump's falsehoods may be the least of it, though. In Harry Frankfurt's terms, Trump is not a liar, but a bullshiter (Frankfurt 2005). Bullshit makes reasoned arguments irrelevant, creating political chaos that undermines the very possibility of civic education. Another commentator writes, "Bullshit is legitimate in politics when everyone starts accepting that words uttered in political discourse do not matter anymore" (Sarajlic 2016). Not coincidentally, Trump supporters had the lowest education levels of any candidate's constituency with an unusually high number of high school dropouts (Masciotra 2016).

Second, repetition: online communication involves repeated exposure to "filter bubbles" or "your own personal, unique universe of information that you have online" (Pariser qtd. in Branstetter 2015). According to the PEW research center, political polarization has increased dramatically in the Internet era, especially since 2000. This is partly because "Websites that use algorithms and data-driven analytics aim to give you what you want politically just as Pandora and Netflix suggest music and movies you might like" (Branstetter 2015). Repetition also occurs when cable news, bloggers, and aggregators repost headline news. In April 2016, memorandum showed that Trump had the lead story $38 \%$ of the time, since declaring his candidacy. When GOP stories led the news, $68 \%$ of the time they were about Trump (Silver 2016). Those trends have continued since he was elected President (Patterson 2017). Trump "trolls" the media, making inflammatory statements to create the controversy that prompts clicks and coverage (Russell 2015). The media succumbs to Trump's trolls partly because political coverage already relies on the "horserace frames" and "status storylines" of neoliberal aesthetics (Reuning and Dietrich 2019).

Third, contagion: according to Dan McAdams (2016), "Trump appeals to an ancient fear of contagion, which analogizes out groups to parasites and poisons." Contagion is closely associated with authoritarian politics and involves mechanisms - name-calling, building walls, and, at its most extreme, practicing genocide -- to keep the good in and the bad out. In his Tweets, Trump engages in misogynist, racist name-calling: Crooked Hillary, Lyin' Ted, Crazy Bernie, Jeb Bushy, Pocahontas, and more recently, Quid Pro, Joe and Shifty Schiff. ${ }^{8}$ Rhetoric replaces reasoned arguments here and creates a distorted reality. In 2016, when his supporters became violent at his rallies, Trump defended his "passionate" followers and offered to pay their legal fees for assault charges. As one commentator put it, "Even before he was a candidate, Trump displayed a rare gift for cultivating the dark power of a crowd" (Sullivan 2016). Recall his highly successful online "birther" campaign against Barack Obama in 2008. Then fast forward to Roger Stone's threat to "dox" 2016 GOP convention delegates by posting their addresses online. "Doxing" is a technique used to harass, shame, bully, and prompt vigilante justice. Many feared that Trump's online mob would take over the streets of Cleveland during the Republican National Convention. Fortunately, that was not the case. However, Trump supporters moved their Internet violence into the streets of Charlottesville, Virginia in 2017, carrying Tiki torches and chanting "Jews will not replace us." Online and in person, Trump's slogans create "a sense of shared injury" that fuels anger, hatred, and violence among his supporters.

David Lebow compares Trump to a "rebellious punk rocker" and describes the alt-right as his "shock troops." In Lebow's words, "today, racial chauvinism, xenophobia, religious intolerance, and misogyny seem to the alt-right to bear an aura of artistic alienation" (2019: 392). He concludes that Trump's chaotic leadership promotes "agitators," "disruptive characters" who "challenge liberal democratic society through an illiberal aesthetic that releases repressed aggression" (Lebow 2019: 392). In this context, it is worth noting that Le Bon also associated crowds with "feminine," 
"child-like," and "savage" qualities, "such as impulsiveness, irritability, incapacity to reason, the absence of judgment and of the critical spirit, the exaggeration of the sentiments, and others besides" (2001: 16). Trump crowds not only exhibit this decline in civility, but also mirror the seeming chaos and underlying inequalities of neoliberal capitalism.

\section{| Trump as Artist: Dealing in Walls}

The Democrats are saying loud and clear that they do not want to build a Concrete Wall - but we are not building a Concrete Wall, we are building artistically designed steel slats, so that you can easily see through it . . . It will be beautiful and, at the same time, give our Country the security that our citizens deserve. It will go up fast and save us BILLIONS of dollars a month once completed!

(Trump, qtd. in Karni and Stolbert 2019)

In Walled States, Waning Sovereignty (2017), Wendy Brown presciently featured photos of an existing steel slat wall without spikes on portions of the Mexican/US border. She also argued that globalization would prompt the building of more walls, including walls within walls, such as gated communities within settler states. Contemporary border wall projects differ from previous border walls because their supposed purpose is less to deter the armies or the armed missiles of other sovereign states than to stop the transnational flows of refugees and smugglers, drugs and guns, capital and terror. Border walls today mark the decline of sovereign nation-states and with them the Westphalian order, a decline produced by global "free" markets, universal human rights, and massive population movements. If national sovereignty is defined in Max Weber's terms, as "a human community that (successfully) claims the monopoly of the legitimate use of force within a given territory," then the felt need to build walled states symbolizes its continuing decline (1918: 78). These new walls also symbolize the increasing separation between sovereignty and the state or, more precisely, the dispersion of sovereign power to a variety of transnational actors. From this perspective, Trump's border wall fits well with his isolationist stance and tariff policies. As America's President-cum-CEO, he is defending the declining (white male) economic and political sovereignty of the West.

Political scientists, of course, have long known that state sovereignty requires more than government or administration. It also requires a vision of the national community (Jacobs, King, and Milkis 2019). According to Benedict Anderson, a nation-state is an "imagined community": it "is imagined because the members of even the smallest nation will never know most of their fellow-members, meet them, or even hear of them, yet in the minds of each lives the image of their communion" (Anderson 2010: 6). That image includes the requirements that define who is and is not a citizen, whether by birthright, shared culture, or both. Even though a state may claim to defend universal values, such as equal rights, it cannot be universal in a world composed of other states. Often the "imagined community" of a nation-state contradicts and compromises its own principles of citizenship. For example, African-American slavery and Native American genocide undermined the principle of equal rights that American democracy claims to represent. When Donald Trump defends nationalism, the imagined community he and his supporters envision is a "white nation." As Adam Serwer (2017) puts it: "Americans act with the understanding that Trump's nationalism promises to restore traditional boundaries of race, gender, and sexuality. The nature of that same nationalism is to deny its essence, the better to salve the conscience and spare the soul."

Trump's plans to build a wall on the US/Mexico border should be seen in this larger historical 
context. When he tweets "it will be beautiful and, at the same time, give our Country the security its citizens deserve," describes "a design of our Steel-Slat Barrier which is totally effective while at the same time beautiful," and insists that "this is not a 2000-mile concrete structure from sea-tosea. These are steel barriers in high priority locations. Much of the border is already protected by natural barriers such as mountains and water," Trump is arguably engaged in projection (Trump 2018; Trump, qtd. in Karni and Stolbert 2019). He needs to build a spiked steel slat barrier to hold back his inner demons; it is a wall of defense against psychological abjection projected onto so-called illegal aliens from "s**hole countries." Trump's personal demons are also writ large on the American national psyche with its continued denials of racism, sexism, and xenophobia. John Dewey, whose alternative - and democratic -- aesthetic I discuss in the next section, claims that projection is never solely an act of the self; it is a collective phenomenon, a shared experience of a social environment. From this perspective, white working-class support for Trump reflects not only "economic distress," but also "white fragility" (Green and McElwee 2019). The latter describes the incapacity of many whites, especially white males, to have serious conversations about the history of racism and xenophobia in America. ${ }^{9}$ When Trump crowds shout "BUILD THAT WALL" and "SEND HER BACK," they reinvoke the claims to white settler supremacy that undergird an imagined white America.

By eroding state sovereignty, neoliberal capitalism has made these efforts to (re)construct an imagined white nation more difficult in some respects. Democracies are - or should be -governed by Constitutional principles, established institutions, and legal norms. The international system of nation-states also has formal properties, such as, international law and international organizations that deregulated global markets lack. The Internet is a similarly unregulated global space. Angela Nagle colorfully sums up the neoliberal blogosphere: "This culture is a blog with no posts and all comments" (qtd. in Lebow 2019: 392). From this perspective, the conspiracy theories that Trump creates to mobilize crowds and justify walls provide much-needed cognitive maps. By targeting "Others," Trump orders the chaos and reinforces the inequality of neoliberal capitalism. By closing the deal for the wall, Trump gives conspiracy-theory-as-cognitive-map material reality on the US/Mexico border. Its proposed "artistically designed steel slats" are a symbolic and territorial -- masterpiece of white nationalism and neoliberal aesthetics.

\title{
| Art, Deals, and Democracy
}

\begin{abstract}
"Works of art are the most intimate and energetic means of aiding individuals to share in the arts of living. Civilization is uncivil because human beings are divided into non-communicating sects, races, nations, castes, and cliques" (Dewey 1934: 336).
\end{abstract}

According to John Dewey, architecture is a shaping art: it "bends natural materials and forms of energy to serve some human desire." Dewey continues, "No other products exhibit stresses and strains, thrusts and counterthrusts, gravity, light, cohesion, on a scale at all comparable to the architectural" (1934: 239). He argues that "buildings, among all art objects, come the nearest to expressing the stability and endurance of existence" (Dewey 1934: 240). The "aesthetic values in architecture are peculiarly dependent upon the absorption of meaning drawn from collective human life" (Dewey 1934: 242). This absorption of meaning is not confined to architecture alone but shared by all art forms. "Art also renders men aware of their union with one another in origin 
and destiny" (Dewey 1934: 282).

As we have seen, Trump uses neoliberal markets and social media to shape his buildings, crowds, and walls. As a candidate and now president, his deal-making on social media, especially Twitter, is arguably most striking. Many political experts and pundits have been blindsided by Trump's deal-making ability. One wonders why: internet technology may be new, but crowd psychology and aesthetic politics are not. Nearly a century ago, John Dewey and Walter Lippmann debated media influence on democratic publics (Schudson 2008; Crick 2009; Celmer 2014; DeCesare 2012).

In The Phantom Public, Walter Lippmann famously characterizes - and caricatures democratic publics and electoral politics. He writes:

\begin{abstract}
But what in fact is an election? We call it an expression of the popular will. But is it? We go into a polling booth and mark a cross on a piece of paper for one of two, or perhaps three or four names. Have we expressed our thoughts on the public policy of the United States?.... The public does not select the candidate, write the platform, outline the policy any more than it builds the automobile or acts the play. It aligns itself for or against somebody who has offered himself, has made a promise, has produced a play, is selling an automobile. The action of a group as a group is the mobilization of the force it possesses (2015: 46-47).
\end{abstract}

According to Lippmann, the notion that majority rule is superior to other forms of political decision-making is a faint democratic echo of the divine right of kings. In fact, neither majorities nor kings speak with "the voice of God," though candidates may enhance their prestige by pretending otherwise. Lippmann argues that "the justification of majority rule....is to be found in the sheer necessity of finding a place in civilized society for the force which resides in the weight of numbers" (2015: 47).

For Lippmann, "the omnicompetent, sovereign citizen" is a "false ideal." While desirable in principle, voters will never be sufficiently engaged or informed to realize it (2015: 29). Stereotypes and symbols -- not principles - align democratic majorities behind "their" candidates. In Public Opinion, Lippmann claims that "systems of stereotypes" determine what voters see and who they are; stereotypes reinforce "our own sense of our own value, our own position and our own rights" (1945: 96). Because stereotypes are closely associated with individual and group identities, they are "highly charged with the feelings that are attached to them. They are the fortress of our tradition, and behind its defenses we can continue to feel ourselves safe in the position we occupy" (1945: 96, emphasis mine). Effective political leaders "move a crowd" to align with a candidate by using symbols that represent familiar stereotypes. While stereotypes retain some cognitive meaning, albeit distorted and simplified, symbols "assemble emotions after they have been detached from their ideas" (2015: 37). Lippmann argues that “... where masses of people must cooperate in an uncertain and eruptive environment, it is usually necessary to secure unity and flexibility without real consent. The symbol does that" (2015: 238).

Anticipating critics of online “filter bubbles," Lippmann argues that print media - newspapers and magazines -- do little to counter stereotypes and symbols or to inform the voting public. Readers typically identify with particular news sources, and journalists follow their news organizations' established conventions. Long before Trump's post-factual politics, Lippmann challenged the perception that journalists uphold "objective standards." He distinguishes between what is "news" and what is true. The news has an episodic, partial quality; it is like a "searchlight" that illuminates passing events. Democratic institutions require a broader and steadier light source, or what Lippmann calls "an organized machinery of knowledge" (2015: 365). Professional experts 
create this body of knowledge that leaders in finance, industry, and politics require. Democratic majorities cannot produce such knowledge, nor can it enlighten their leaders. According to Lippmann, "the force of public opinion is partisan, spasmodic, simple-minded, and external" (2015: 141). He concludes that "A false ideal of democracy can lead only to disillusionment and to meddlesome tyranny.... The public must be put in its place, so that it may exercise its own powers, but no less and perhaps even more, so that each of us may live free of the trampling and the roar of a bewildered herd" (2015: 145).

In his commentary on Lippmann's Public Opinion, John Dewey concedes that Lippmann has "thrown into clearer relief than any other writer the fundamental difficulty of democracy" (1922: 286). However, Dewey draws a different conclusion. He argues that so fundamental a problem requires an even more fundamental solution:

Democracy demands a more thoroughgoing education than the education of officials, administrators, and directors of industry. Because this fundamental general education is at once so necessary and so difficult of achievement, the enterprise of democracy is so challenging. To sidetrack it to the task of enlightenment of administrators and executives is to miss something of its range and its challenge (1922: 288).

In The Public and Its Problems, Dewey agrees with Lippmann that the "omnicompetent citizen" was an illusion perpetrated by earlier proponents of democracy (1954: 157-159). Democracy has so far failed to transform established customs, institutions, and practices. It has instead merely transferred power between classes.

Dewey maintained that the "physical tools of communication" already available in his day could renew the possibility of a more robust democracy (1954: 142). For Dewey, the public is more than a mere aggregation of voters; properly understood, voters represent the public and it acts through them. An informed voting public cannot be "mass-produced," but must instead be educated through communication with others in society (1954: 116). The purpose of education is never "mere majority rule"; it is how a majority becomes a majority and a society becomes a community (1954: 107). Dewey insists that "Till the Great Society is converted into a Great Community, the Public will remain in eclipse" (1954: 147).

According to Dewey, "Communication of the results of social inquiry is the same thing as the formation of public opinion.... For public opinion is judgment which is formed and entertained by those who constitute the public and is about public affairs" (1954: 177). How to improve the conditions for public debate so that democratic publics can emerge is the central problem that democracies face. Stereotypes and symbols that merely reinforce the status quo must be continually challenged by "free social inquiry" and the "art of communication." For Dewey, "The function of art has always been to break through the crust of conventionalized and routine consciousness" (1954: 183). Along with the press, "Artists have always been the real purveyors of news, for it is not the outward happening in itself which is new, but the kindling by it of emotion, perception, and appreciation" (1954: 184).

I am not suggesting that Dewey, who also called for a new political economy, thought the arts alone could create the conditions for democratic self-determination. Instead, he raises the question of whether the arts can still foster sufficient distance from neoliberal realities for democratic publics to practice critical thinking and reflective judgment. The stunning success of Trump's neoliberal aesthetic has revealed the vulnerability of democratic publics to the cognitive maps that conspiracy theories provide. Yet on December 18, 2019, the US House of Representatives passed articles of impeachment that accuse President Trump of abuse of power 
and obstruction of Congress. At this writing, it remains to be seen whether and, if so, when those articles of impeachment will be sent to the Senate for trial. Nancy Pelosi's decision as Speaker of the House to hold onto them until the Senate commits to a "fair process" that "would honor the Constitution" reaffirms the importance of legal institutions in democratic governance (qtd. in Faulders and Siegel 2019). The polls currently indicate that Trump's base remains steadfast despite his impeachment, or perhaps because of it.

Will the arts of democracy eventually prevail over Trump's art of the deal? The upcoming 2020 presidential race gives this question new urgency. It poses new risks of violent crowds and state surveillance becoming a new "normal" - a process compounded by space/time compression (Pariser 2012; Keen 2015; Coleman 2015). The neoliberal combination online of global information flows, expressive politics, and dispersed networks continues to undermine the collective agency of democratic publics. Jürgen Habermas addresses this last issue in "Political Communication in Media Society: Does Democracy Still Enjoy an Epistemic Dimension? The Impact of Normative Theory on Empirical Research.” Although he recognizes that the Internet has "reactivated the grassroots of an egalitarian public of writers and readers," he now limits the "democratic merits" of the Internet to popular resistance to authoritarian regimes. In liberal democracies, "the rise of millions of fragmented chat rooms across the world tend instead to lead to the fragmentation of large but politically focused mass audiences into a huge number of isolated issue publics." Online debates make positive contributions to public discourse only when they "crystallize around the focal points of the quality press." Habermas thinks this rarely occurs $(2006$; 2014). He also considers possible solutions to the pathologies of political communication today. He argues that democratic deliberation requires: 1) "a self-regulated media system"; 2) and "the right kind of feedback between mediated political communication and civil society" (Habermas 2006: 420). The first would prevent politicians from hijacking the media and, the second, would preclude media shifts in focus from political education to depoliticized entertainment. Only when these requirements are met will democratic publics be protected from politicians like Trump, who see "We, the People" as the(ir) next best deal.

\section{Closing Thoughts Amidst Impeachment Prospects}

In "The Search for a Purveyor of News: The Dewey/Lippmann Debate in an Internet Age," Nathan Crick argues that the most pressing question today is how best to facilitate critical thinking and reflective judgment, and whether these qualities are necessarily limited to experts or can be made accessible to a wider public (2009: 480). He argues that the Internet offers new spaces for experts and non-experts to experience the democratic effects of what Dewey broadly defines as "art": “...the blogosphere creates new opportunities for experts and citizens to interact in cooperative processes of inquiry, and... allows journalists and artists to generate more expansive creative networks while providing a new medium for aesthetic communication" (Crick 2009: 495). These opportunities have not been fully embraced for democratic purposes and have too often replicated neoliberal priorities of "corporate profits" and "individual expression" (2008: 495).

However, the Internet has served some democratic purposes, for example crowd-sourcing constitutions, mobilizing protest movements, and promoting global civil society (Shirky 2009; Chavez 2010; Bennett 2012; Gould 2014; Burgess and Keating 2016). In addition, democratic artworks continue to feature aesthetic alternatives that suggest different cognitive maps. In "The Smugglers: The Rationality of Political Satire in the 2014 Elections," Jamie Warner argues that 
political satire smuggles in rational arguments that spoof the "infoenterpropagainment" that dominates the news today (Warner 2016). Warner analyzes comedy shows, specifically, Stephen Colbert 's The Colbert Report and The Late Show and Jon Stewart's The Daily Show. For my purposes here, Illma Gore's nude portrait of Donald Trump with a micropenis, entitled "Make America Great Again" and the public furor over it online may provide the best example of the power of political satire (Frank 2016). Viewing Gore's portrait, one could conclude that Trump's wall - like his towers and crowds - is a sexual fetish. ${ }^{10}$ All too often, the "shock effect" of artwork like Gore's portrait, and the ensuing critical discussion, are necessary to bring an audience or a citizenry to their senses (Lara 2008).

Social media may provide as yet unrealized opportunities to build a democratic community through political communication (Umayasiri 2006; Surowiecki 2004). Although Dewey and Lippmann shared this ultimate goal, they proposed different ways to realize it. While Lippmannn relied on "the experts," Dewey had confidence that ordinary citizens could use the arts and popular culture to become adequately informed and engage critically with candidates and policies. The aesthetics of neoliberalism have also made this process more difficult by overwhelming many citizens, increasing political polarization, and reducing potential leaders to deal-makers. Today what democratic publics may need most are "bubble-bridging public intellectuals," that is, 21st-century renditions of Gramsci's organic intellectuals, who can foster the arts of democracy that Dewey envisioned (Gramsci 1999; Fraser 2017; O’Connor, 2019).

An exploration of the new aesthetic forms that could link such public intellectuals with ordinary citizens leads well beyond the scope of this article. In closing, for now, Marshall McLuhan famously said that "the message of any medium or technology is the change of scale or pace or pattern that it introduces into human affairs" (1994: 1). With Trump's campaign, presidency, and now impeachment, the online strategies are new, but the neoliberal messages -- buildings, crowds, walls -- are not. Instead, the conspiracy theories Trump creates as cognitive maps make the structural inequalities of capitalist, patriarchal, white supremacy "democracy" manifest. If George Will was correct about the "brashness, zest, and élan" of the American national character, we might hope that a Deweyan "art of organization of human activities" can still emerge to show that Trump's "art of the deal" is not normal. In these challenging times, Dewey can remind us that democracy is not a deal; it is a community in which all peoples "share in the arts of living" (Dewey, 1934: 336). 


\section{Endnotes}

1. My thanks to Nate Arnold and John Neal for research assistance. Portions of this paper were previously presented at the 2019 American Political Science Association, Washington, DC, the 2019 Caucus for a New Political Science Conference, South Padre Island, TX, the 2016 Colloquium on Philosophy and the Social Sciences, Institute of Philosophy, Academy of Sciences of the Czech Republic, Prague, CZ, the 2016 American Political Science Association Convention, Philadelphia, PA. I am grateful to discussants on several panels for their suggestions.

2. In a 1926 speech, Benito Mussolini spoke of the complex relationship between art and politics: "That politics is an art there is no doubt.... Political like artistic creation is a slow elaboration and a sudden divination. At a certain moment the artist creates with inspiration, the politician with decision. Both work the material and the spirit.... In order to give wise laws to a people it is also necessary to be something of an artist" (qtd. in Falasca-Zamponi, 2000:15).

3. Hitler regarded propaganda as the most important political art. In Mein Kampf, he famously described the "the art of propaganda" as "understanding the emotional ideas of the great masses and finding, though a psychologically correct form, the way to the attention and thence to the heart of the broad masses." He added that "The receptivity of the great masses is very limited, their intelligence is small, but their power of forgetting is enormous. In consequence of all these facts, all effective propaganda must be limited to a very few points and must harp on slogans until the last member of the public understands what you want him to understand by your slogan” (Hitler, 1971:61).

4. I have written elsewhere about the prominent role white power music plays in the current rise of white supremacy in western liberal democracies (Love 2016). Regarding Trump's musicality, in particular, Daniel Oore (2018) argues that he deploys lexical, kinesthetic, auditory, and most important mythic gestures continually to assemble, disassemble, and reassemble his presidential body as the body politic.
5. Sheldon Wolin (2008) distinguishes "classical fascism" with its principle of strong, hierarchical, and charismatic leadership from the "inverted totalitarianism" of today that turns elected leaders into corporate managers and citizens into consumers/clients of the neoliberal order.

6. Some psychologists argue that Trump's "grandiosity" typifies a narcissistic personality in his need to be the center of attention and win approval from others (McAdams 2016).

7. Unlike pre-industrial crowds, modern crowds have held the power to create, destroy, and shape governments, at least, since the American and French revolutions.

8. See https://en.wikipedia.org/wiki/List_of_ nicknames_used_by_Donald_Trump

9. In "Settler Fragility: Why Settler Privilege Is So Hard To Talk About" (2018), Dina Gilio Whitaker builds on Robin D'Angelo's earlier article to argue that "white supremacy is also at the root of settler fragility. The difference is that foreign invasion, dispossession of Indigenous lands, and genocide were based on (white) European religious and cultural supremacy as encoded in the doctrine of discovery, not racial supremacy. And, unlike other people of color who have made significant legal gains in the US political system, the nearly two-centuries-old doctrine of discovery is at the foundation of the legal system that still paternalistically determines Native lives and lands."

10. S E Cup suggested as much on "Unfiltered," January 26, 2019. Also, recall Stormy Daniels retort "Tiny" when Trump called her "Horseface," and the extended discussion of Trump's small hands during the 2016 campaign. 


\section{References}

Abu-Hamdi, Eliana (2017) "Neoliberalism as a site specific process: the aesthetics and politics of archi-

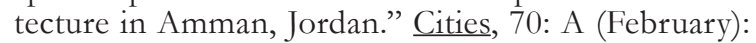
102-112.

Ahmed, Sara (2015) The Cultural Politics of Emotion. New York, NY: Routledge.

Anderson, Benedict (2010) Imagined Communities: reflections on the origin and spread of nationalism, revised edition. London: Verso.

Beinart, Peter (2016) “The Republican Party's White Strategy, Embracing white nativism in the 1990s turned the California GOP into a permanent minority. The same story may now be repeating itself nationally," The Atlantic July-August.

Bennett, W. Lance (2012) "The Personalization of Politics: Political Identity, Social Media, and Changing Patterns of Participation," The Annals of the American Academy 644(1): 20-39.

Branstetter, Gillian (2015) "The Internet Created Bernie Sanders and Donald Trump and It's Killing Moderates," The Daily Dot September 14.

Brown, Wendy (2017) Walled States, Waning Sovereignty. Brooklyn, NY: Zone Books.

Burgess, Susan and Christine (Cricket) Keating (2014) "Occupy the Social Contract! Participatory Democracy and Iceland's Crowd-Sourced Constitution," pp. 115-129 in Nancy S. Love and Mark Mattern (eds.) Studying Politics Today: Critical Approaches to Political Science. New York, NY: Routledge.

Buric, Fedja (2016) 'Donald Trump's Not Hitler, He’s Mussolini: How GOP Anti-Intellectualism Created a Modern Fascist Movement in America," Salon March 11.

Byrd, Haley, Manu Raju and Phil Mattingly, "Nancy Pelosi Won't Commit to Sending Articles of Impeachment to the Senate," CNN December 19.

Campoy, Ana (2018) "More Than 60\% of Donald Trump's Twitter Followers Look Suspiciously Fake," Quartz October 12. https://qz.com/1422395/howmany-of-donald-trumps-twitter-followers-are-fake/

Celmer, Matthew (2014) "The Solution to the DeweyLippman Debate," The Graduate Research Journal, 1: 49-58.

Chaves, Elisabeth (2010) “The Internet as Global Platform: Grounding the Magically Levitating Public Sphere," New Political Science: A Journal of Politics and Culture 32(1): 23-41.
CNN, "Read CNN's Interview with Stormy Daniels," March 10, 2018. Retrieved 3/7/2019 from the World Wide Web. https://www.cnn.com/2018/03/10/ politics/stormy-daniels-cnn-interview-transcript/ index.html

CNN, "Former Playboy Model Speaks Out On Time With Trump." Retrieved 3/7/2019 from the World Wide Web. https://www.cnn.com/videos/ us/2018/03/23/karen-mcdougal-full-interview-ac.cnn

Coleman, Gabriella (2015) Hacker, Hoaxer, Whistleblower, Spy: The Many Faces of Anonymous. New York, NY: Verso.

Costello, Maureen B. (2016) "Teaching the 2016 Election: The Trump Effect: The Impact of the Presidential Campaign on Our Nation's Schools," Southern Poverty Law Center April 13.

Cottle, Michele (2016) "How Donald Trump Opened the Way for David Duke's Return,” The Atlantic August 8.

Crick, Nathan (2009) "The Search for a Purveyor of News: The Dewey/Lippmann Debate in an Internet Age," Critical Studies in Media Communication, 26 (5): 480-497.

Cup S E (2019), “Unfiltered,” CNN January 26.

D’Angelo, Robin (2011) “White Fragility,” International Journal of Critical Pedagogy, 3(3): 54-70.

DeCesare, Tony (2012) "The Lippmann-Dewey "Debate" Revisited: The Problem of Knowledge and the Role of Experts in Modern Democratic Theory," Philosophical Studies in Education, 43: 106-116.

Dewey, John. (1922) "Public Opinion," The New Republic. May 3: 286-288.

(1934) Art as Experience. New York, NY: Penguin Books.

- (1954) The Public and Its Problems. Chicago, IL: The Swallow Press.

Elliott, Jane and Gillian Harkins (2013) "Introduction," Genres of Neoliberalism Special Issue, Social Text, 31(2): 1-17.

Falasca-Zamponi, Simonetta (2000) Fascist Spectacle: The Aesthetics of Power in Mussolini's Italy. Berkeley, CA: University of California Press.

Faulders, Katherine and Benjamin Siegel (2019) "Pelosi: Not Sending Impeachment Articles to Senate Until She Sees Details of Trial Process," ABC News December 20. 
Frank, Priscilla (2016) "Artist Imagines What Donald Trump Looks Like Naked and It Ain't Pretty," The Huffington Post February 11.

Frankfurt, Harry (2005) On Bullshit. Princeton, NJ: Princeton University Press.

Fraser, Nancy (2017) "From Progressive Neoliberalism to Trump-and Beyond," American Affairs. 17: 4, (Winter). https:// americanaffairsjournal.org/2017/11/ progressive-neoliberalism-trump-beyond/

Friedman, Milton (2002) Capitalism and Freedom: Fortieth Anniversary Edition. Chicago, IL: University of Chicago Press.

Friedman, Uri (2017) "What Is A Populist? And Is Donald Trump One?", The Atlantic February 27.

Gibbs, Anna (2010) “After Affect: Sympathy, Synchrony, and Mimetic Communication," pp. 186-206 in The Affect Theory Reader, Melissa Gregg and Gregory J. Seigworth (eds.). Durham, NC: Duke University Press.

Gould, Carol C. (2014) Interactive Democracy: The Social Roots of Global Justice. Cambridge, UK: Cambridge University Press.

Gramsci, Antonio (1999) Selections From the Prison Notebooks, ed. and trans. by Quentin Hoare and Geoffrey Nowell Smith. London, UK: ElecBook.

Green, Jon and Sean McElwee (2019) "The Differential Effects of Economic Conditions and Racial Attitudes in the Election of Donald Trump," Perspectives on Politics. 17:2 (June): 358-379.

Habermas, Jürgen (1991) The Structural Transformation of the Public Sphere, trans. Frederick Lawrence. Boston, MA: MIT Press.

(2006) "Political Communication in Media Society: Does Democracy Still Enjoy an Epistemic Dimension? The Impact of Normative Theory on Empirical Research," Communication Theory 16: 411-426.

(2014) interview by Markus Schwering, "Internet and Public Sphere, What the Web Can't Do," Feuilleton of the Frankfurter Rundschau of 14/15 (June).

Hilton, Nick (2018) “The Aesthetics of Donald Trump: Unpacking the Iconography of a Man and a Movement," Medium May 15.

Hirsch, Lily E. (2018) "Weapons of Mass Distraction: Music, Trump, and Democracy," pp. 239-261 in Eric T. Kasper and Benjamin Schoening, You Shook Me All Campaign Long: Music in the 2016 Presidential Campaign and Beyond. Denton, TX: University of North Texas Press.
Hitler, Adolf (1971), Mein Kampf, trans. Ralph Manheim. New York, NY: Houghton Mifflin.

Holley, Peter (2016) “Top Nazi Leader: Trump Will Be A Real Opportunity for White Nationalists," The Washington Post August 7.

Karni, Ani and Cheryl Gay Stolbert (2019) "Donald Trump Offers Temporary Protections for 'Dreamers' in Exchange for Wall Funding," New York Times January 19.

Keen, Andrew (2015) The Internet Is Not the Answer. New York, NY: Atlantic Monthly Press.

Kessler, Glenn, Salvador Rizzo, and Megan Kelly (2018) "President Trump has made 7,465 false or misleading statements over 710 days," The Fact Checker, Analysis (December 21 updated December 30).

Jacobs, Nicholas F., Desmond King, and Sidney M. Milkis (2019) "Building a Conservative State: Partisan Polarization and the Redeployment of Administrative Power," Perspectives on Politics, 17(2): 453-459.

Lara, Maria Pia (2008) Narrating Evil: A PostMetaphysical Theory of Reflective Judgment. New York: Columbia University Press.

Le Bon, Gustave (2001) The Crowd: A Study of the Popular Mind. Waterloo, Ontario, Canada: Kitchener.

Lebow, David (2019) "Trumpism and the Dialectic of Neoliberal Reason," Perspectives on Politics, 17 (2): 380-398.

Lee, Timothy B. (2016) "How the internet is disrupting politics," Vox, technology March 14 https:/ / www.vox. com/2016/3/14/11211204/sanders-trump-disrupting-politics .

Lippmann, Walter (1945) Public Opinion. New York, NY: The MacMillan Co.

(2015) The Phantom Public. New Brunswick, NJ: Transaction Publishers.

Love, Nancy (2016) Trendy Fascism: White Power Music and the Future of Democracy. Albany, NY: SUNY Press.

Masciotra, David (2016) "We let the idiots take the wheel: Donald Trump, Fox News and how we let our democracy rot," Salon April 1.

McAdams, Dan P. (2016) “The Mind of Donald Trump." The Atlantic June.

McCarthy, Tom (2018) "Is Donald Trump an Authoritarian? Experts Examine Telltale Signs," The Guardian November 18.

McLuhan, Marshall and Lewis H. Lapham (1994) Understanding Media: The Extensions of Man. Boston, MA: MIT Press. 
McWilliams, Matthew (2016) “The One Weird Trait That Predicts Whether You Are a Trump Supporter, And It's Not Gender, Age, Income, Race, or Religion," Politico January 17.

Michaels, Walter Benn (2011) "Neoliberal Aesthetics: Fried, Ranciere, and the Form of the Photograph" nonsite.org, 1 April 25.

Mikkelson, David (2016) "Lawsuit Charges Donald Trump With Raping A 13-Year Old Girl," Snopes June.

O’Connor, Daniel, personal conversation.

Oore, Daniel (2018) “Trump the Musical Prophet,"pp. 273-316 in Eric T. Kasper and Benjamin S. Schoening (eds.) You Shook Me All Campaign Long: Music in the 2016 Presidential Election and Beyond. Denton, Texas: University of North Texas Press.

Osnos, Evan (2016) “Trump's Convention Strategy: The Fix is In," The New Yorker April 8.

Pariser, Eli (2012) The Filter Bubble: How the New Personalized Web Is Changing What We Read and How We Think. New York, NY: Penguin.

Patterson, Thomas E (2017) "News Coverage of Donald Trump's First 100 Days," Shorenstein Center, May 18. https://shorensteincenter.org/ news-coverage-donald-trumps-first-100-days/

Politifact, "All False Statements Involving Donald Trump." Retrieved on 12/19/2019 from the World Wide Web. https://www.politifact.com/personalities/ donald-trump/statements/byruling/false/

Reuning, Kevin and Nick Dietrich (2019) "Media Coverage, Public Interest, and Support in the 2016 Republican Invisible Primary," Perspectives on Politics, 17(2): 326-339.

Russell, Fred (2015) "How Donald Trump Is An IRL Internet Troll," Rise News September.

Sarajlic, Eldar (2016) “Donald Trump's Reign of Bullsh*t: He's Not Lying To Us, He's Just Completely Full of It," Salon March 27.

Schnapp, Jeffrey T. (1996) "Fascinating Fascism," Journal of Contemporary History, Special Issue: The Aesthetics of Fascism 31: 2 (April ): 235-244.

Schudson, Michael (2008) “The 'Lippmann-Dewey Debate' and the Invention of Walter as an AntiDemocrat 1986-1996," International Journal of Communication 2: 1-20.

Schulte-Sasse, Linda (1991) "Leni Riefenstahl's Feature Films and the Question of a Fascist Aesthetic," Cultural Critique 18 (Spring): 123-149.
Serwer, Adam (2017) “The Nationalist's Delusion: Trump's supporters backed a time-honored American political tradition, disavowing racism while promising to enact a broad agenda of discrimination," The Atlantic November 20.

Shafer, Byron E. and Regina L. Wagner (2019) “The Trump Presidency and the Structure of Modern American Politics," Perspectives on Politics, 17(2): 340-357.

Shapiro, Rebecca (2019) 'Yo-Yo Ma Jabs Donald Trump as He Plays Cello on Both Sides of U.S.-Mexico Border," Huffington Post April 14.

Shirky, Clay (2009) Here Comes Everybody: The Power of Organizing Without Organizations. New York, NY: Penguin.

Silver, Nate (2016) "How Donald Trump Hacked the Media: Trump Dominance on Cable News Isn't the Whole Story," Five/Thirty/Eight March 30.

Sontag, Susan (1980) "Fascinating Fascism," pp. 73-108 in Under the Sign of Saturn. New York, NY: Farrar, Straus, and Giroux.

Srnicek, Nick (2015) "Navigating Neoliberalism: Political Aesthetics in an Age of Crisis," Medium: After Us October 19.

Stanley, Jason (2019) “Our Increasingly Fascist Public Discourse," Project Syndicate January 25.

Sullivan, Andrew (2016) "Democracies End When They Are Too Democratic: America Has Never Been So Ripe for Tyranny," New York Magazine May 1.

Surowiecki, James (2004) The Wisdom of Crowds, Why The Many Are Smarter Than The Few And How Collective Wisdom Shapes Business, Economies, Societies, and Nations. New York, NY: Doubleday.

Toure, (2016) “Donald Trump's White Lives Matter Movement," The Huffington Post March 18.

Trump, Donald with Kate Bohner (1997) Trump: The Art of the Comeback. New York, NY: Random House.

with Tony Schwartz (2015) Trump: The Art of the Deal. New York, NY: Ballantine Books.

. Tweets on 10/15/18, 12/18/18, and 12/21/18.

Ubayasiri, Kasun "Internet and the Public Sphere: A glimpse of YouTube," self-published manuscript. ejournalist.com/v6n2/ubayasiri622.pdf .

Warner, Jamie (2016) “The Smugglers: The Rationality of Political Satire in the 2014 Elections," PS: Political Science and Politics February. 
Weber, Max (2018) “Politics As A Vocation” pgs. 77-128 in H.H. Gerth, et. al., From Max Weber: Essays in Sociology. New York, NY: Oxford University Press, 1946.

Wheeler, Marcy (2016) "Donald Trump is Terrorizing America: Why His Lurid Media Spectacles Have Something in Common With Isis," Salon April 1.

Whitaker, Dina Gilio (2018) "Settler Fragility: Why Settler Privilege Is So Hard To Talk About," Beacon Broadside November 14.

Wilkie, Christina (2016) "'The Trump Effect": Hatred, Fear, and Bullying On the Rise in Schools," HuffPost Politics April 13.

Wolin, Sheldon (2008) Democracy Incorporated: Managed Democracy and the Spectre of Inverted Totalitarianism. Princeton, NJ: Princeton University Press. 